\title{
Zróżnicowanie przestrzenne sily ekonomicznej wiodących przedsiębiorstw w regionie świętokrzyskim
}

Sytuacja gospodarcza województwa świętokrzyskiego nie należy do najlepszych w kraju. Poziom rozwoju gospodarczego jest wyraźnie niższy od poziomu większości województw. W ostatnich latach stan ten ulega jednak poprawie, szczególnie za sprawą prorozwojowej działalności największych regionalnych przedsiębiorstw.

Głównym celem opracowania jest przedstawienie zróżnicowania przestrzennego siły ekonomicznej dominujących przedsiębiorstw w gospodarce województwa. Zakres przestrzenny analiz doprecyzowano poprzez wybór jednostek terytorialnych, na których obszarze zlokalizowały swoje siedziby (zarządy) określone działalności. Czołowe podmioty, w liczbie 120, zostały wyróżnione na podstawie Rankingu największych firm województwa świętokrzyskiego „,Ztota setka”" („Echo Dnia”, 12.09.2008 r.), w którym kryterium porządkowania były przychody ze sprzedaży towarów i usług za 2007 r. Wraz z wysokością przychodów siłę ekonomiczną zbiorowości wyrażono na podstawie wielkości zatrudnienia oraz liczby powiązań kapitałowo-osobowych. Uwzględniono przy tym jej strukturę własnościową oraz rodzajową. Odniesiono się do rozkładu działalności ogółu podmiotów gospodarki narodowej (wg sekcji PKD 2007) w regionie świętokrzyskim, w tym do zmiany struktury w latach 1995-2007.

Obok zestawienia, niezbędne były dla studium badawczego szczegółowe i aktualne (stan na 2009 r.) informacje pochodzące z Banku Danych Regionalnych GUS, Krajowego Rejestru REGON, Krajowego Rejestru Sądowego, komercyjnych baz danych o firmach (obszerne serwisy: Hoppenstedt Bonnier Information i Info Veriti), jak również zaczerpnięte ze źródeł pierwotnych, tj. z oficjalnych stron internetowych podmiotów. Rejestry urzędowe pomogły ustalić m.in. dokładne adresy siedzib przedsiębiorstw, a bazy komercyjne - stan powiązań wskazujących inne podmioty z KRS, z którymi związani są udziałowcy danej spółki.

\section{SilA EKONOMICZNA W ŚWIETLE RANKINGU}

W klasyfikacji największych firm znalazło się 51 (42,5\%) spółek z ograniczoną odpowiedzialnością, 48 (40\%) spółek akcyjnych, 8 spółek jawnych, 6 spółdzielni, 5 osób fizycz-

\footnotetext{
${ }^{1}$ Badania ankietowe do rankingu z grona ponad 200 przedsiębiorstw wyodrębniły listę 100 najprężniej rozwijających się firm oraz 20 aspirujących do tego grona, o dużym potencjale rozwoju. W pracy wszystkie uznano za wiodące.
} 
nych prowadzących działalność gospodarczą, samodzielny publiczny zakład opieki zdrowotnej i stowarzyszenie. Suma ich przychodów wyniosła 25,0 mld zł, a kształtowały się one w przedziale od 9,9 mln zł do 3,1 mld zł. Osiągnięte zostały łączne zyski w wysokości 1,7 mld zł, natomiast straty - dla 3 firm - wynosiły 2,2 mln zł. Podmioty zatrudniały 53,1 tys. osób. Liczba wszystkich ustalonych powiązań kapitałowo-osobowych wyniosła 14,1 tys.

Podstawową dziesiątkę wiodących przedsiębiorstw w każdym aspekcie zdominowały grupy kapitałowe, których w badanej zbiorowości było $12^{2}$. Największą pod względem przychodów była Grupa Kolporter (3,1 mld zł), drugim podmiotem - Celsa Huta Ostrowiec (2,5 mld zł), trzecim - Grupa Cersanit (1,5 mld zł). Jeszcze 5 kolejnych firm wykazało obroty powyżej 1 mld zł: ZEORK i Grupa Pilkington Polska (po 1,3 mld zł), Elektrownia Połaniec (1,2 mld zł), Lafarge Cement oraz Grupa Polskie Składy Budowlane (po 1,1 mld zł). Dziesięć spółek koncentrowało 57,7\% ogółu przychodów. Wysoka sprzedaż towarów, produktów i usług najlepiej świadczy o sile rynkowej podmiotu, zdolności zdobywania nowych nabywców, jego konkurencyjności.

W zakresie liczby powiązań finansowo-osobowych czołową pozycję zajęła Grupa Echo Investment (2,7 tys.). Kolejne 3 podmioty miały średnio ponad 4 razy mniej powiązań Nowa Gala, Cersanit, Kolporter; PZF Cefarm-Kielce, Magellan Pro-Equity Fund I i Nomi - średnio 6 razy mniej; zaś Zakłady Mięsne Animex, Barlinek, Mostostal Kielce - przeszło 8 razy mniej. Wszystkie wyróżnione koncentrowały 49,2\% ogółu powiązań. Trzeba wspomnieć, iż 8 na 10 pierwszych jednostek mieściło się w stolicy województwa. Największe struktury powiązań, zagregowane do poziomu gmin, miały miejsce w Kielcach (8,4 tys.), Starachowicach (927) i Końskich (891). Lokalizacja siedziby przedsiębiorstwa w dużym ośrodku miejskim, pełniącym jednocześnie gospodarcze funkcje kontrolne, determinuje w dużej mierze stan jego powiązań. Dążność do tworzenia różnych sieci powiązań to jeden z głównych elementów mechanizmów rynkowych.

Na uwagę zasługuje ranking firm według wielkości zatrudnienia. Średnioroczne zatrudnienie w 3 pierwszych grupach kapitałowych znacznie przekroczyło 2 tys. osób i cechowało Cersanit (6,3 tys.), Kolporter (3,2 tys.) oraz Barlinek (2,9 tys.). Czwarty podmiot, Pilkington Polska, wraz z 7 następnymi (Nomi, NSK Bearings Polska, Exbud Skanska, Huta Celsa, Fabryka Kotłów SEFAKO, ZM Animex, ZPUE) zatrudniał więcej niż 1 tys. osób. Pracujący w tych 11 firmach stanowili 42,7\% zatrudnionych. Wysoki stan zatrudnienia zwykle dotyczy działalności produkcyjnych, co potwierdzają wykazane przypadki.

\section{NAJSILNIEJSZE PODMIOTY W UJĘCIU STRUKTURALNYM}

Rozmieszczenie wiodących podmiotów z jednoczesnym uwzględnieniem ich wielkości nie odbiegało od znanych prawidłowości (ryc. 1). W 18 miastach skoncentrowanych było 105 (87,5\%) siedzib przedsiębiorstw. Pozostałe znajdowały się na 13 obszarach wiejskich, a połowa przypadków dotyczyła 6 gmin powiatu kieleckiego. Miasto Kielce było miejscem lokalizacji 55 jednostek. Łącznie z powiatem ziemskim rejon kielecki skupił ok. $52 \%$ firm. Kolejne ośrodki nie były tak znaczącymi miejscami koncentracji, ale wśród nich warto wyróżnić Ostrowiec Świętokrzyski, Starachowice, Końskie. Stanowią one podstrefy

\footnotetext{
2 To wada tego rankingu, ponieważ skonsolidowano dane o takich spółkach, przyjmując wartości dotyczące spółki macierzystej z regionu, grupującej podległe jej podmioty.
} 
wchodzące w skład Specjalnej Strefy Ekonomicznej „Starachowice”. W podstrefie Końskie zlokalizowane zostały 2 dominujące podmioty, tj. Nowa Gala i Grupa Ceramika-Końskie, a $1 \mathrm{w}$ Starachowicach - Cerrad ${ }^{3}$. Rozpatrując przy tym strukturę wielkościową (wg zatrudnienia), przedsiębiorstwa średnie stanowiły $1 / 2$, zaś duże - przeszło 1/3 ogółu. Na obszarach zurbanizowanych zidentyfikowano 3 największe podmioty, 8 bardzo dużych, 40 dużych, 48 średnich oraz 6 firm mikro i małych. Z kolei na obszarach wiejskich były 2 duże spółki, 12 średnich i 1 mała firma.

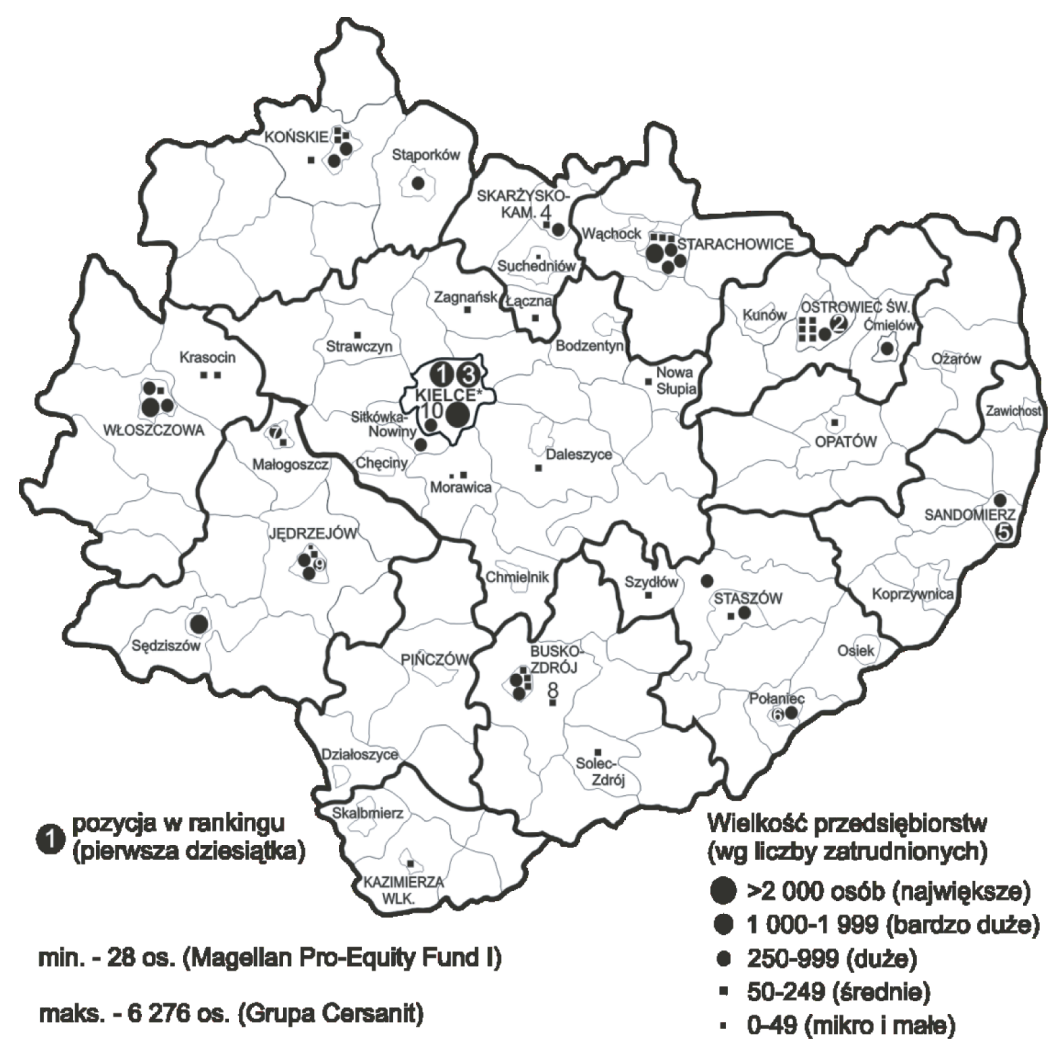

Ryc. 1. Rozmieszczenie i wielkość wiodących przedsiębiorstw województwa świętokrzyskiego w $2007 \mathrm{r}$.

*Nie uwzględniono położenia 51 z 55 podmiotów na obszarze Kielc

Źródło: Opracowanie własne na podstawie: Ranking... (2008)

Czynników lokalizacji, jak też ich typologii, istnieje wiele. W umiejscowieniu siedzib przedsiębiorstw główną rolę odgrywają współcześnie zjawiska ekonomiczne, społeczne i polityczne. Przy tym, na obszarze województwa w dalszym ciagu można odczuć skutki gospodarki centralnie planowanej oraz wpływ (pozytywny i negatywny), z początku nieod-

\footnotetext{
${ }^{3}$ FK SEFAKO (Sędziszów), Zakłady Urządzeń Kotłowych Stąporków, Alpol Gips (gmina Końskie) i Anna-Bud (gmina Morawica) to pozostałe wiodące firmy działające w SSE.
} 
powiednio realizowanej (w kluczowej wstępnej fazie „,przełomu”), transformacji do systemu gospodarki rynkowej, której etap końcowy trwa od chwili przystąienia Polski do Unii Europejskiej (Rogacki 2007, s. 165). W związku z tym podjęto próbę zaklasyfikowania siedzib wiodących przedsiębiorstw według typów organizacyjno-przestrzennych ich lokalizacji w okresie przemian, których przypadki dla przestrzeni miast wyróżnił P. Śleszyński (2008, s. 30). Tak więc typologia wskazała 17 jednostek, które istniały przed 1989 r. i które kontynuują swoją działalność, nie zmieniając zasadniczo struktury organizacyjnej oraz siedziby (typ A). Firm powstałych przed 1989 r., które przeszły gruntowną restrukturyzację, bez zmiany siedziby (B), było 42 (35\%). Wśród działalności, które zaistniały po 1989 r., 3 przeniosły zarządy w nowe miejsca przestrzeni miejskiej, bez zmiany struktury (C). Także 3 podmioty, powstałe po 1989 r., zmieniły swe struktury i siedziby (D). Największą grupę, w liczbie 55 (45,8\%), tworzyły nowe firmy, które w naturalny sposób ulokowały się w danym miejscu $(E)^{4}$. Obecne rozmieszczenie dominujących przedsiębiorstw w większości powstało z przekształcenia pierwotnych struktur gospodarczych, jak również z ustaleń nowych przemyślanych lokalizacji.

Miejsce położenia każdej działalności jest związane w gruncie rzeczy z maksymalizacją efektywności, co utożsamia się z wielkością przychodów przedsiębiorstwa oraz jego wizerunkiem i prestiżem. Nie bez znaczenia pozostaje charakter prowadzonego przedsięwzięcia oraz jego forma własności. W strukturze rodzajowej badanych podmiotów (ryc. 2) najwyższy odsetek przypadał na sekcję przetwórstwa przemysłowego (42,5\%), następnie na sekcje: handlową i naprawczą $(20,8 \%)$ oraz budowlaną (10\%). Aktywności produkcyjne oraz handlowe stanowiły miejsca pracy dla 43,7\% i 36\% zatrudnionych. Średnio po $40 \%$ kwoty przychodów wygenerowały 2 najliczniejsze sekcje, trzykrotnie mniej - jednostki branży energetycznej. Uogólniając, wiodące firmy województwa działają głównie w sektorze przemysłu i budownictwa $(65 \%)$ oraz usług rynkowych $(32,5 \%)$. Zatrudnienie wyniosło odpowiednio $55 \%$ i $42 \%$. Grupa przemysłowa osiagnęła $14,5 \mathrm{mld}$ zł, a usługowa - 10,4 mld zł obrotów. Dominowały krajowe przedsiębiorstwa prywatne (68,3\%), co piąte było własnością publiczną, a przewaga kapitału zagranicznego wystąpiła w 14 spółkach.

Analiza rozkładu przestrzennego według działalności wskazuje na rozproszenie wiodących przedsiębiorstw o typie przemysłowym. Znajdowały się one na ponad 3/4 wyróżnionych obszarów, z czego najwięcej w Kielcach (15; 29,4\% sekcji C), Końskich (5), Starachowicach i Włoszczowie (po 4). Przedsiębiorstwa handlowe zlokalizowano w 5 miastach (Kielce, Jędrzejów, Sandomierz, Kazimierza Wielka, Suchedniów) oraz na obszarze wiejskim gminy Busko Zdrój, ale i w tym przypadku dominowała stolica regionu z 19 (76\%) firmami sekcji. Podobnie rzecz się ma w branży budowlanej - poza Kielcami (2/3 grupy) pojedyncze jednostki były w Ostrowcu Świętokrzyskim, Jędrzejowie, Małogoszczy i w gminie Morawica. Najbardziej zróżnicowana struktura rodzajowa dotyczyła centrów powiatowych. Potwierdzono również prawidłowość, iż sekcje usługowe koncentrują się częściej w ośrodku o najwyższym szczeblu administracyjnym, a przemysł na niższych szczeblach terytorialnych.

\footnotetext{
${ }^{4}$ Przykłady firm wg typów lokalizacji: A - Społem PSS (Kielce), Uzdrowisko Busko-Zdrój; B - Celsa Huta Ostrowiec, Lhoist Bukowa; C - Barlinek, Cersanit (Kielce); D - Kolporter (Kielce), Lafarge Cement (Małogoszcz); E - Frega, Unimax (Kielce).
} 


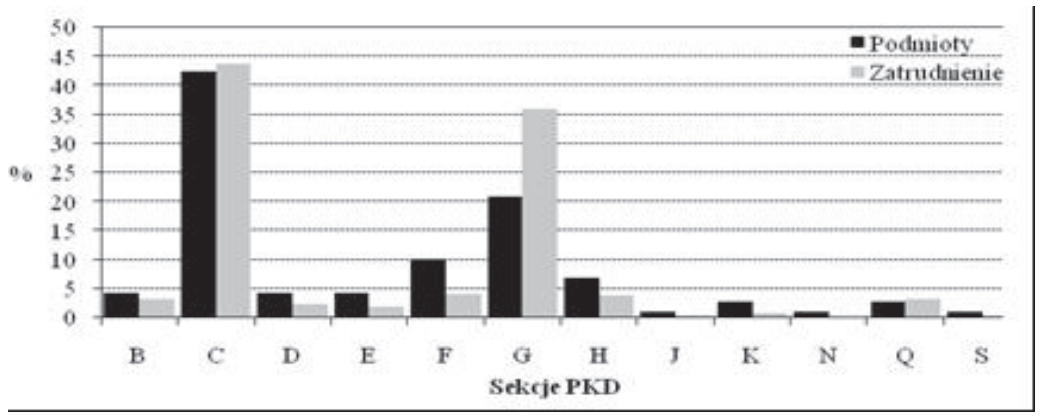

Ryc. 2. Struktura rodzajowa wiodących przedsiębiorstw województwa świętokrzyskiego według liczby podmiotów i zatrudnienia w $2007 \mathrm{r}$.

Sekcje: B - górnictwo, C - przetwórstwo przemysłowe, D - elektroenergetyka, E - dostawa wody, gospodarowanie ściekami i odpadami, F - budownictwo, G - handel i naprawy, H - transport i gospodarka magazynowa, $\mathrm{J}$ - informacja i komunikacja, $\mathrm{K}$ - pośrednictwo finansowe, $\mathrm{N}$ - działalności wspierające, Q - opieka zdrowotna i pomoc społeczna, $\mathrm{S}$ - pozostała działalność usługowa

Źródło: Opracowanie własne na podstawie: Ranking... 2008, Krajowy Rejestr... 2009

W związku z powyższym dało się zauważyć dysproporcje wysokości przychodów według głównych rodzajów działalności w zależności od lokalizacji siedziby w mieście lub na obszarze wiejskim (ryc. 3). Najwyższe obroty osiągnęły wiodące przedsiębiorstwa przemysłowe położone na obszarach miast (90,5\% przychodów sektora), w szczególności Kielc i Ostrowca Świętokrzyskiego (po 2,8 mld zł). Analogiczna sytuacja dotyczyła usług rynkowych (89,4\% obrotów sektora), w tym $3 / 4$ przychodów odnoszą się do samych Kielc. W grupie obszarów wiejskich warto wymienić Busko Zdrój, na którego terenie ulokował siedzibę 1 podmiot handlowy (Polskie Składy Budowlane) mający 10,5\% udziału w obrotach grupy usługowej oraz Sitkówkę-Nowiny, gdzie przychód z działalności produkcyjnej (Dyckerhoff Polska) przekroczył 0,5 mld zł.

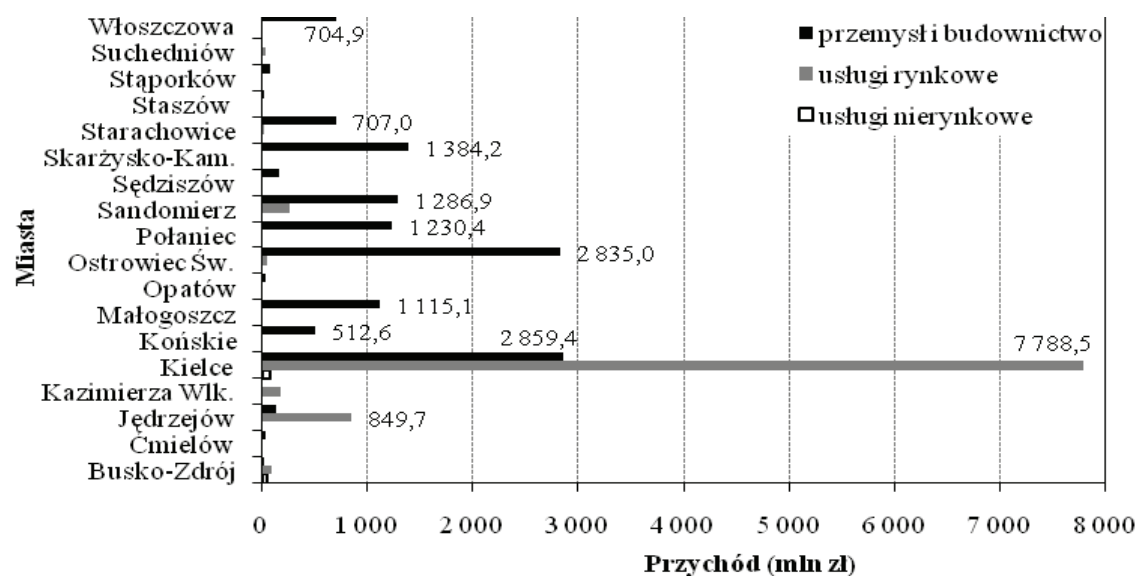

Ryc. 3. Przychody wiodących przedsiębiorstw województwa świętokrzyskiego w miastach według rodzajów działalności w $2007 \mathrm{r}$.

Źródło: Opracowanie własne na podstawie: Ranking... 2008, Krajowy Rejestr... 2009 
Biorąc pod uwagę strukturę przychodów dominujących firm województwa według form własności, największy ich odsetek $(60,9 \%)$ wystapił w grupie o prywatnym krajowym kapitale, drugie miejsce zajęły spółki zagraniczne (35\%), niewielki udział przypadł podmiotom Skarbu Państwa (4,2\%). Rozpatrując zgodnie z tym rozmieszczenie skumulowanych przychodów, z uwzględnieniem struktury własnościowej (ryc. 4), widać, że praktycznie wszystkie wiodące jednostki o obrotach do $100 \mathrm{mln}$ zł to polskie prywatne firmy. Większość z nich zlokalizowano na obszarach wiejskich, resztę w małych ośrodkach miejskich (m.in. Suchedniów i Ćmielów). W pozostałych przypadkach rozkład przychodów nie był tak jednoznaczny. Związane jest to przeważnie z nagromadzeniem podmiotów, które z kolei uzależnione jest od tendencji rynkowych, rodzaju i rozmiaru działalności czy preferencji lokalizacyjnych inwestorów. W drugim przedziale przychodów prywatne krajowe przedsiębiorstwa, z siedzibami w Końskich, Włoszczowie, Sędziszowie i Kazimierzy Wielkiej, wypracowały w całości wartość obrotów grupy. Wyróżniają się już w tej kategorii jednostki sektora zagranicznego zlokalizowane w gminach Sitkówka-Nowiny i Krasocin. W omawianej strukturze kapitał prywatny krajowy miał największe znaczenie w tworzeniu obrotów nie większych niż 1 mld zł. W grupie o wyższych przychodach przeważająca ich część była w rękach zagranicznych i dotyczyła przedsiębiorstw skoncentrowanych w Małogoszczy (98\%), Połańcu (95\%), Ostrowcu Świętokrzyskim (87\%) i Sandomierzu (83\%). Kielce skumulowały 10,7 mld zł przychodów, z czego udział firm prywatnych stanowił $78 \%$, a zagranicznych $-17 \%$.

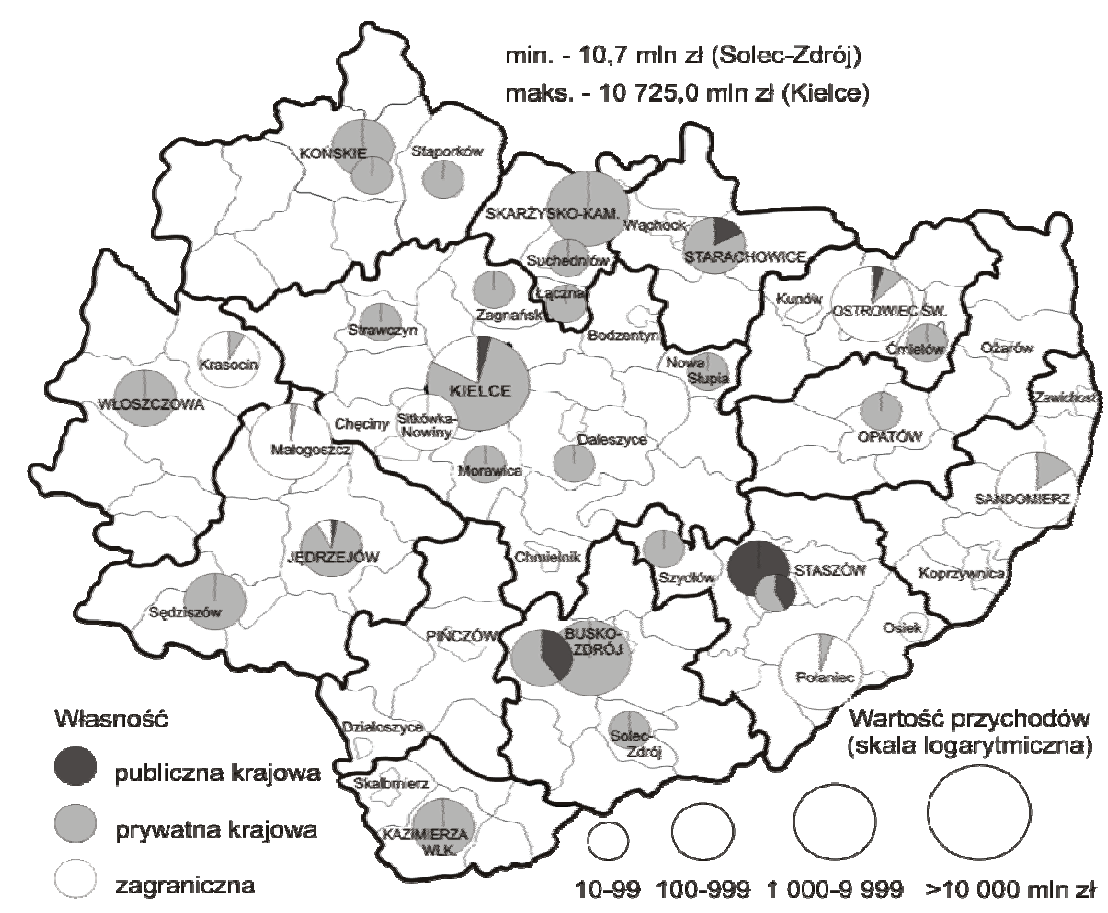

Ryc. 4. Przychody wiodących przedsiębiorstw województwa świętokrzyskiego według struktury własnościowej w $2007 \mathrm{r}$.

Źródło: Opracowanie własne na podstawie: Ranking..., Krajowy Rejestr... 2009 


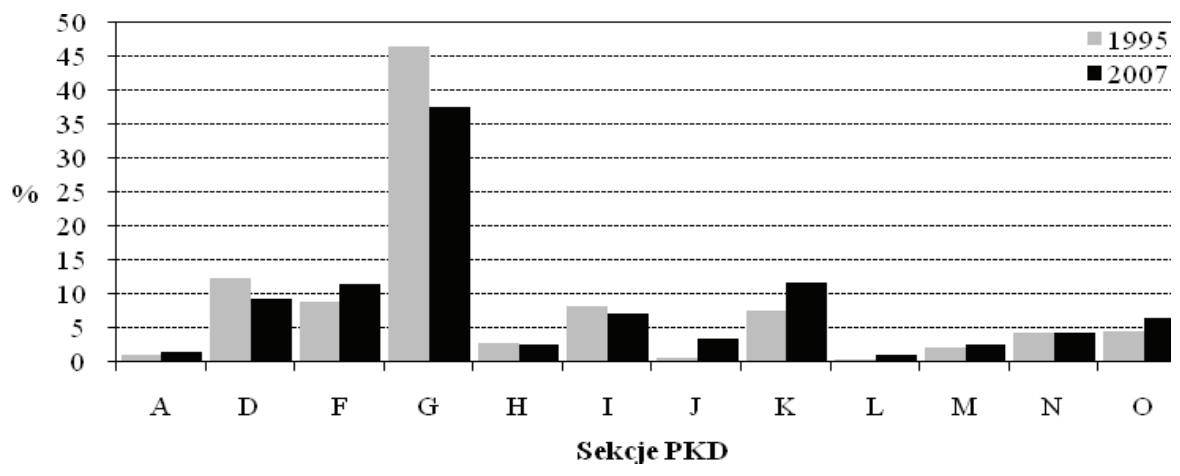

Ryc. 5. Struktura rodzajowa podmiotów gospodarki narodowej w województwie świętokrzyskim według sekcji PKD* w latach 1995 i 2007

*Sekcje o udziale poniżej $0,4 \%$ nie zostały uwzględnione

Sekcje: A - rolnictwo i leśnictwo, D - elektroenergetyka, F - budownictwo, G - handel i naprawy, H - transport i gospodarka magazynowa, I - zakwaterowanie i usługi gastronomiczne, $\mathrm{J}$ - informacja i komunikacja, $\mathrm{K}$ - pośrednictwo finansowe, $\mathrm{L}$ - obsługa nieruchomości, $\mathrm{M}$ - działalności profesjonalne, $\mathrm{N}$ - działalności wspierające, $\mathrm{O}$ - administracja publiczna i obrona narodowa, zabezpieczenia społeczne.

Źródło: Opracowanie własne na podstawie: dane GUS (BDR), Krajowy Rejestr... 2009

Struktura rodzajowa wiodących przedsiębiorstw, w związku z przyjętym sposobem ich wyodrębnienia, nie odzwierciedla struktury na poziomie regionalnym. Warto wobec tego odnieść się do rozkładu działalności w województwie świętokrzyskim, z uwzględnieniem jego zmiany w latach 1995-2007 (ryc. 5). We wskazanym okresie liczba zarejestrowanych podmiotów wzrosła dwukrotnie, z 52,0 tys. do 107,0 tys. Poza tym nastapiły przekształcenia jakościowe struktury świadczące o unowocześnianiu regionalnej gospodarki. Zauważalnie zmniejszył się odsetek dominującej sekcji handlu i napraw (o 9\%) oraz elektroenergetycznej (o 3\%). Zwiększył się natomiast udział działalności pośrednictwa finansowego (o 4\%), informacji i komunikacji (o 2,8\%), budownictwa (o 2,6\%), czy też aktywności wspierających (o 2\%). Liczba podmiotów drugiej z wyróżnionych branż (m.in. wydawnictwa, usługi informatyczne) podniosła się w największym stopniu, z 377 do 3,7 tys., tj. prawie dziesięciokrotnie. Dalszy wzrost znaczenia tych działalności umożliwi zmianę wciąż niekorzystnej struktury gospodarki województwa, gdzie odnotowuje się nadal niezadowalający poziom rozwoju inwestycji. Nakłady inwestycyjne na jego obszarze w 2007 r. miały wartość 4,1 mld zł (2,1\% w skali kraju), z czego 50,9\% ulokowano w przemyśle, a 45,9\% w usługach.

\section{Podsumowanie}

W świetle przeprowadzonej analizy stwierdza się, że umiejscowienie wiodących przedsiębiorstw regionu, działalność oraz rodzaj własności wpływają w dużym stopniu na prezentowaną przez nie siłę ekonomiczną.

Istotna większość uwzględnionych firm, szczególnie tych o największej sile rynkowej, zlokalizowana jest w miastach. Wyłania się w tym względzie przeważająca rola Kielc, które 
są administracyjnym oraz gospodarczym centrum, mieszczącym w skali województwa 27\% (28,9 tys.) podmiotów. Wyraźną koncentrację przestrzenną najlepszych przedsiębiorstw potwierdzają również inne badania przeprowadzone na gruncie krajowym (m.in. Wyżnikiewicz 1997; Śleszyński 2002, 2008; Lijewski 2003; Rogacki 2006). Taka sytuacja niestety przekłada się na dysproporcje w rozwoju przedsiębiorczości w regionie. Na 10 tys. mieszkańców przypada w nim ok. 813 podmiotów (średnia krajowa to 948), ponadto między miastem a wsią istnieje ponaddwukrotna różnica wielkości wskaźnika przedsiębiorczości (Regionalny Program... 2008, s. 12).

Należy zaznaczyć, iż prorozwojowa działalność największych firm przyczynia się w ostatnich latach do przekształcania obecnej struktury gospodarki województwa świętokrzyskiego, z przeważającymi nieefektywnymi i tradycyjnymi działami. Podmioty gospodarcze są podstawowym źródłem finansowania działalności badawczo-rozwojowej (B+R) w regionie, ponosząc przeszło $50 \%$ nakładów $^{5}$ (średnio w Polsce jest to ok. 25\%). Jednym z głównych bodźców tych przedsięwzięć jest idea stworzenia w granicach Unii Europejskiej nowoczesnej i innowacyjnej gospodarki. Bardzo poważną szansę rozwoju społeczno-gospodarczego stanowią dla województwa świętokrzyskiego aktywności związane przede wszystkim z budownictwem, odlewnictwem, czy też tzw. usługową działalnością wspierająca. Dominujące spółki, takie jak: Dorbud, Echo Investment, Celsa Huta Ostrowiec, Exbud Skanska, Targi Kielce, to tylko niektóre przykłady wskazanego potencjału. Coraz powszechniej realizują one koncepcje współpracy w ramach odpowiednich klastrów, tj. klastra budowlanego, odlewniczego (Świętokrzyskie Zagłębie Odlewniczo-Kooperacyjne) oraz targowo-kongresowo-usługowego (Grono Targowe Kielce). Geograficzna koncentracja pobudza procesy kooperacji i konkurencji, co przekłada się na rozwój danego obszaru. Korzystając w pełni z możliwości, jakie przyniosły nowe formy współpracy oraz integracja z gospodarką światową i europejską, przedsiębiorstwa wiodące jak i słabsze mogą znacząco zwiększyć oraz utrwalić swą siłę rynkową, budując dzięki temu konkurencyjną, opartą na wiedzy i generującą miejsca pracy regionalną gospodarkę.

\section{Literatura}

Baza danych o przedsiębiorstwach Info Veriti, 2009, Info Veriti Polska, Warszawa, http://www.infoveriti.pl

Baza danych o przedsiębiorstwach Hoppenstedt Bonnier Information, 2009, HBI Polska, Płock, https://www.hbi.pl

Krajowy Rejestr Urzędowy Podmiotów Gospodarki Narodowej REGON, 2009, GUS, Warszawa, http:// www.stat.gov.pl/regon/

Lijewski T., 2003, Koncentracja ośrodków aktywności gospodarczej w Polsce w świetle list 500 firm, Przegląd Geograficzny, nr 53, 3, s. 433-447

Ranking największych firm województwa świętokrzyskiego „Ztota setka” (Edycja I), „Echo Dnia”, 12.09.2008

Regionalny Program Operacyjny Województwa Świętokrzyskiego na lata 2007-2013, 2008, Urząd Marszałkowski Województwa Świętokrzyskiego, Kielce

Rogacki H., 2006, Large industrial enterprises in Poland: changes in the regional pattern, Questiones Geographicae, no 25, s. 53-59

\footnotetext{
${ }^{5}$ Nakłady na te cele z budżetu państwa stanowiły w 2007 r. 42\% łącznej kwoty 35,6 mln zł, a od instytucji nauki $-2 \%$. W porównaniu z $2006 \mathrm{r}$. ich wartość wzrosła o 14,1 mln zł.
} 
Rogacki H. (red.), 2007, Geografia społeczno-gospodarcza Polski, Wydawnictwo Naukowe PWN, Warszawa

Śleszyński P., 2002, Struktura i rozmieszczenie ośrodków zarzqdzania w polskiej gospodarce $w 2000$ r., Przegląd Geograficzny, nr 74, 2, s. 199-228

Śleszyński P., 2008, Duże przedsiębiorstwa w strukturze przestrzennej największych polskich miast, Prace Geograficzne nr 217, IGiPZ PAN, Warszawa

Wyszukiwarka podmiotów w Krajowym Rejestrze Sqdowym, 2009, Ministerstwo Sprawiedliwości, Warszawa, http://krs.cors.gov.pl

Wyżnikiewicz B., 1997, Regionalne zróżnicowanie sity ekonomicznej (na podstawie „Listy 500” największych przedsiębiorstw Gazety Bankowej), [w:] G. Gorzelak (red.), Przemiany polskiej przestrzeni, Studia regionalne i lokalne, nr 19 (52), Europejski Instytut Rozwoju Regionalnego i Lokalnego UW, Warszawa, s. 205-228

\section{Spatial diversity of leading enterprises' economic power in the Świętokrzyskie Region}

The economic performance of Świętokrzyskie Voivodeship is not one of the best in the country. The level of its development is visibly lower than in the majority of provinces. However, this situation is improving, especially due to development-oriented activities of the largest regional companies. The present study shows the spatial diversity of leading enterprises' economic power in the Świętokrzyskie Region. The market power of the enterprises which were selected from among 120 of the leading entities was determined on the basis of the following factors: income value, number of employees and the number of capital and personal relationships. The ownership and generic structures were also taken into consideration.

Mgr Patryk Brambert

Uniwersytet Humanistyczno-Przyrodniczy im. Jana Kochanowskiego w Kielcach

Instytut Geografii

Zakład Geografii Ekonomicznej i Gospodarki Przestrzennej

e-mail: patryk.brambert@ujk.edu.pl 